\title{
China English: Attitudes, legitimacy, and the native speaker construct
}

\author{
JETTE G. HANSEN EDWARDS
}

\author{
Is China English becoming accepted as a legitimate variety \\ of English?
}

\section{Introduction}

China English (CE) is the fastest growing variety of English in the world. While some estimate that there are between 200-400 million learners of English in mainland China, other researchers put the numbers between 440-650 million (cf. Bolton \& Graddol, 2012; He \& Zhang, 2010). Although not all learners of English in China will become active users of English, the numbers above are staggering, especially if we consider that the population of the United States is currently 319 million (United States Census Bureau, 2014). As Kirkpatrick (2007: 151) notes, CE is 'soon likely to be the most commonly spoken variety of English in Asia'. One could argue that, judging by the numbers given above, $\mathrm{CE}$ will become the most commonly spoken variety of English in the world.

Despite the rapid growth of CE, only a few studies have examined attitudes towards $\mathrm{CE}$, particularly in terms of whether $\mathrm{CE}$ is perceived as a legitimate variety of English by speakers of English in China, whether an individual can be a native speaker (NS) of CE, and why these attitudes are held. The current study therefore seeks to address these issues via a survey study conducted with 123 tertiary students from China. The results offer important insights into how CE is defined, perceived and used by speakers of English in China.

\section{Literature review}

The past decade has seen an increase in the recognition and acceptance of CE. While early research on CE (see Hu, 2004; Kirkpatrick \& Xu, 2002) found that few tertiary students wanted to speak English with a Chinese accent, or had even heard of $\mathrm{CE}$, later research found more positive attitudes towards CE. He and $\mathrm{Li}$ (2009) found that the majority of their respondents had heard of $\mathrm{CE}$ and believed that one day $\mathrm{CE}$ would exist as a legitimate variety of English. However, these respondents still preferred an exonormative model of English pronunciation. He and Zhang (2010) surveyed college teachers in China and found that the majority felt that a $\mathrm{CE}$ accent was acceptable as long as the speech was comprehensible.

While it appears that attitudes towards CE in China have become more favorable in recent years, as demonstrated by the research findings

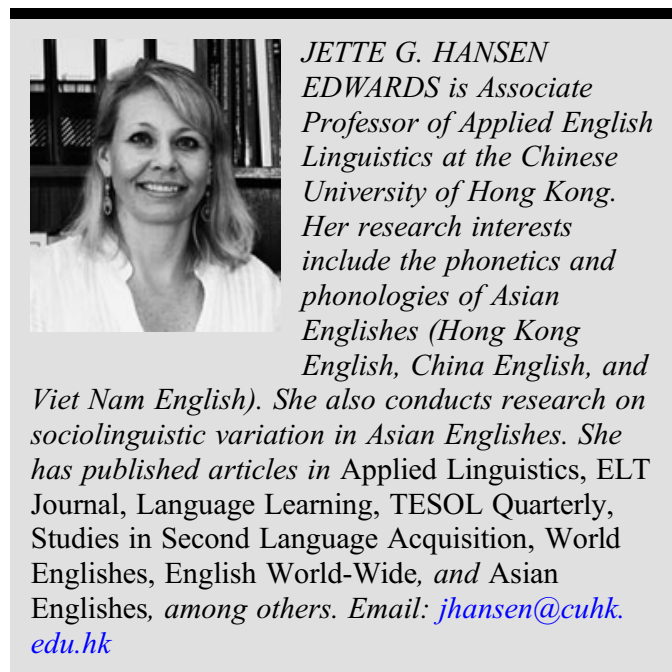


discussed above, it is not clear why speakers of English in China do or do not accept $\mathrm{CE}$ as a legitimate variety of English, and what reasons and criteria they give to justify the lack of its legitimacy. The current study also probes the construct of the NS in light of the emergence of $\mathrm{CE}$ as a variety of English. As world Englishes researchers (see Bolton, 2008; Schneider, 2010) note, NS definitions are becoming increasingly problematic as we are observing shifts in the way English is learned and used in both outer and expanding circle countries. The current study probes the question of whether a person can be a native speaker of CE. It is likely that when new Englishes, such as CE, gain acceptance, speakers of these Englishes may begin to view English as 'theirs', rather than as the purview of speakers of inner circle Englishes. As a result, the view of who can be a native speaker of English may expand from an inner-circle English norm to speakers of world Englishes, such as CE (see Singh, 1998).

\section{Methodology}

The current study was conducted in October 2014 at a tertiary institute in Hong Kong with a large population of students from China. An online questionnaire was developed, with a total of 123 respondents completing the survey. The survey consisted of demographic questions and closedand open-ended questions addressing the following three research questions:

1. What attitudes do speakers of English in China hold towards CE?

2. Do they perceive CE to be a real variety of English? Why or why not?

3. Do they believe a person can be a NS of CE? Why or why not?

The data analyses provide a summary of the main findings from the closed-ended questions, along with patterns from the open-ended questions. For the open-ended questions, each respondent could write as much as they wanted and therefore some participants' responses were coded for multiple answers. Finally, for a number of questions, responses were analyzed in terms of whether the respondents indicated that they spoke CE in order to determine whether attitudes towards CE differed depending on whether the respondent was a speaker of CE.

The data were initially coded by the author before another researcher independently checked the author's coding of the answers to the openended questions. The raters were in agreement for the majority of the codes, with an inter-rater reliability of $97 \%$. In the few cases when the raters did not agree on the coding, a third rater was asked to code the responses.

\section{Results}

Table 1 provides an overview of the demographics of the participants in the current study. The majority of the respondents were female, between 21 and 25 years old, and full-time students in postgraduate programmes. Nearly three quarters had learned English in China in primary school. The respondents came from every region of mainland China, with 20 out of the 22 provinces $^{1}$ represented as well as the municipalities of Beijing, Chongqing, Shanghai, and Tianjin, and the autonomous regions of Guangxi, Xinjiang Uyghur and Ningxia Hui. The diversity of the geographical (and thus linguistic) backgrounds of the respondents helps ensure the responses reflect the attitudes of speakers of English across China.

In order to examine the acceptance of CE as well as the native speaker construct in relation to $\mathrm{CE}$, the following questions were asked:

Why is or isn't China English a 'real' variety of English?

Why can or can't a person be a native speaker of China English?

Why do you or don't you think you speak CE?

Responses to the first set of questions were coded for patterns, which are presented as categories in the Tables 2, 3, and 4. As participants could write as much as they wanted for each question, some responses were coded for multiple categories. Percentages were calculated based on the number of respondents within each group that gave a similar answer (e.g. 13 out of 49 respondents, or $29 \%$, who said CE was a real variety of English stated it 'has its own unique accent of English').

Of the 123 respondents, $37 \%$ agreed that $\mathrm{CE}$ was a real variety of English, 39\% stated it was not real, and $24 \%$ of respondents stated they were unsure. The main reason respondents felt that $\mathrm{CE}$ was a legitimate variety of English was that $\mathrm{CE}$ had 'many speakers' (38\%). The second reason was the linguistic features, and in particular, the accent $(29 \%)$, vocabulary/expressions $(27 \%)$, and syntax (9\%) unique to $\mathrm{CE}$.

There was less agreement among those who stated that CE was not a real variety of English. 19\% felt it was a learner variety while $17 \%$ stated that English was not an official language in China and that there were too many different kinds of 


\begin{tabular}{|llcc|}
\hline Table 1: Demographics of the participants & & & \\
\hline Demographic & & Number & Percentage \\
\hline Gender & Female & 28 & $23 \%$ \\
\hline Age & $18-20$ & 95 & $77 \%$ \\
\hline & $21-25$ & 34 & $28 \%$ \\
\hline & $26-30$ & 78 & $63 \%$ \\
\hline Degree & $31-35$ & 7 & $5 \%$ \\
\hline Age of beginning English learning & $36-40$ & 2 & $2 \%$ \\
\hline & Undergraduate & 2 & $2 \%$ \\
\hline & Postgraduate & 34 & $28 \%$ \\
\hline & Birth & 89 & $72 \%$ \\
\hline $2-3$ years & 1 & $1 \%$ \\
\hline & $4-5$ years & 5 & $4 \%$ \\
\hline & $6-7$ years & 12 & $10 \%$ \\
\hline & $8-9$ years & 31 & $25 \%$ \\
\hline & $10-11$ years & 29 & $24 \%$ \\
\hline & $12-15$ years & 31 & $25 \%$ \\
\hline
\end{tabular}

Table 2: Why is or isn't China English a 'real' variety of English?

\begin{tabular}{|lccc|}
\hline Reasons & $\begin{array}{c}\text { Yes it is real } \\
n=45 \\
(37 \%)\end{array}$ & $\begin{array}{c}\text { No it is not real } \\
n=48 \\
(39 \%)\end{array}$ & $\begin{array}{c}\text { Unsure } \\
n=30 \\
(24 \%)\end{array}$ \\
\hline Linguistic features & $13(29 \%)$ & $7(14 \%)$ & $3(10)$ \\
\hline Unique accent of English & $0(0 \%)$ & $3(6 \%)$ & $2(7 \%)$ \\
\hline Does not have its own grammar, words & $4(9 \%)$ & $1(2 \%)$ & $0(0 \%)$ \\
\hline Different syntax & $12(27 \%)$ & $2(4 \%)$ & $1(3 \%)$ \\
\hline New words/expressions from Chinese into English & & & \\
\hline International acceptability and intelligibility & $6(13 \%)$ & $0(0 \%)$ & $0(0 \%)$ \\
\hline Accepted internationally & $6(13 \%)$ & $0(0 \%)$ & $1(3 \%)$ \\
\hline Intelligible & $0(0 \%)$ & $9(19 \%)$ & $7(23 \%)$ \\
\hline Learner variety & & & $1(3 \%)$ \\
\hline Environment & $0(0 \%)$ & $8(17 \%)$ & $4(13 \%)$ \\
\hline English not official language in China & $0(0 \%)$ & $8(17 \%)$ & $1(3 \%)$ \\
\hline Too many different kinds of English in China & $17(38 \%)$ & $0(0 \%)$ & $11(37 \%)$ \\
\hline Many speakers of CE & & & $0(0 \%)$ \\
\hline Other & $0(0 \%)$ & & \\
\hline Not sure & & & \\
\hline
\end{tabular}


Table 3: Why can or can't a person be a native speaker of China English?

\begin{tabular}{|c|c|c|c|}
\hline Reasons & $\begin{array}{c}\text { Yes } \\
n=59 \\
(48 \%)\end{array}$ & $\begin{array}{c}\text { No } \\
n=35 \\
(28 \%)\end{array}$ & $\begin{array}{l}\text { Unsure } \\
n=29 \\
(24 \%)\end{array}$ \\
\hline \multicolumn{4}{|l|}{ Linguistic features } \\
\hline Has a unique accent & $2(3 \%)$ & $1(3 \%)$ & $0(0 \%)$ \\
\hline Influenced by Chinese & $10(17 \%)$ & $2(6 \%)$ & $1(3 \%)$ \\
\hline \multicolumn{4}{|l|}{ Environment } \\
\hline Born and raised in China (CE environment) & $21(36 \%)$ & $2(6 \%)$ & $2(7 \%)$ \\
\hline Learned English in an educational context & $12(20 \%)$ & $0(0 \%)$ & $1(3 \%)$ \\
\hline Parents speak CE & $9(15 \%)$ & $0(0 \%)$ & $1(3 \%)$ \\
\hline Many dialects in China so no 'one' English & $0(0 \%)$ & $4(11 \%)$ & $2(7 \%)$ \\
\hline Many speakers of CE & $5(8 \%)$ & $0(0 \%)$ & $0(0 \%)$ \\
\hline \multicolumn{4}{|l|}{ Proficiency and use } \\
\hline Advanced English proficiency & $6(10 \%)$ & $0(0 \%)$ & $0(0 \%)$ \\
\hline Lack of proficiency in English & $0(0 \%)$ & $4(11 \%)$ & $3(10 \%)$ \\
\hline Not used often & $0(0 \%)$ & $4(11 \%)$ & $1(3 \%)$ \\
\hline \multicolumn{4}{|l|}{ History and status } \\
\hline Not mother tongue in China & $0(0 \%)$ & $3(9 \%)$ & $2(7 \%)$ \\
\hline Not official language in China & $0(0 \%)$ & $3(9 \%)$ & $0(0 \%)$ \\
\hline Doesn't exist & $0(0 \%)$ & $10(29 \%)$ & $3(10 \%)$ \\
\hline Not sure & $2(3 \%)$ & $0(0 \%)$ & $12(41 \%)$ \\
\hline
\end{tabular}

English in China for there to be one CE. Finally, respondents who said they were unsure whether $\mathrm{CE}$ was a real variety or not stated they were unsure as to the reason $(37 \%)$, followed by them perceiving it to be a learner variety $(23 \%)$.

Respondents were also asked if a person could be a NS of CE. Table 3 presents these answers to this question. Nearly half of the respondents $(48 \%)$ agreed that a person could be a NS, while $28 \%$ stated 'No' and $24 \%$ were unsure. The major reason respondents gave as to why a person could be a NS of CE related to the environment, with $36 \%$ stating that if one was born and/or raised in China, one could be a NS of CE. Teacher/educational $(20 \%)$ and parental $(15 \%)$ influences were also commonly cited.

The primary reason for why respondents felt that one could not be a NS of CE related to the history and status of CE, with $29 \%$ of these respondents stating that $\mathrm{CE}$ did not exist. Some respondents $(11 \%)$ also stated that since there were many dialects in China, one CE could not exist. Interestingly, this response does not disagree with the possibility of
CE existing, only that one variety could not exist due to the different types of English in China. A second section of the questionnaire was designed to examine the extent to which the speakers themselves spoke CE; these results are outlined in Table 4. Nearly half $(46 \%)$ of the respondents stated they spoke CE, while $19 \%$ stated they did not speak $\mathrm{CE}$, and $35 \%$ were unsure. Linguistic features were the major reasons respondents felt that they spoke CE. They felt their English had a Chinese influence $(33 \%)$ and a unique accent $(26 \%)$.

The reason respondents did not feel they spoke CE was due to proficiency and use, as $43 \%$ of these respondents stated that they tried hard to improve their English so they did not speak CE. Those that were unsure about speaking CE also cited proficiency: $16 \%$ stated they tried hard to learn English so they would not speak CE and $12 \%$ stated they spoke another variety of English.

The 57 participants who said they spoke CE were asked if they liked speaking CE. Answers to this question are presented in Figure 1. The majority $(54 \%)$ said they did not like speaking CE, while 
Table 4: Why do you or don't you think you speak CE?

\begin{tabular}{|c|c|c|c|}
\hline Reasons & $\begin{array}{c}\text { Yes, Do } \\
n=57 \\
(46 \%)\end{array}$ & $\begin{array}{c}\text { No, Don't } \\
n=23 \\
(19 \%)\end{array}$ & $\begin{array}{l}\text { Unsure } \\
n=43 \\
(35 \%)\end{array}$ \\
\hline \multicolumn{4}{|l|}{ Linguistic features } \\
\hline Unique accent & $15(26 \%)$ & $0(0 \%)$ & $3(7 \%)$ \\
\hline Chinese influenced English & $19(33 \%)$ & $0(0 \%)$ & $0(0 \%)$ \\
\hline \multicolumn{4}{|l|}{ Environment } \\
\hline Born and raised in China & $8(14 \%)$ & $0(0 \%)$ & $0(0 \%)$ \\
\hline Parents speak CE & $1(2 \%)$ & $0(0 \%)$ & $0(0 \%)$ \\
\hline Teachers speak CE & $12(20 \%)$ & $0(0 \%)$ & $1(2 \%)$ \\
\hline Friends speak CE & $2(4 \%)$ & $0(0 \%)$ & $0(0 \%)$ \\
\hline \multicolumn{4}{|l|}{ Proficiency and use } \\
\hline I try hard to improve my English so I don't speak CE & $0(0 \%)$ & $10(43 \%)$ & $7(16 \%)$ \\
\hline I speak another variety of English & $0(0 \%)$ & $3(13 \%)$ & $5(12 \%)$ \\
\hline Not sure & $0(0 \%)$ & $0(0 \%)$ & $14(33 \%)$ \\
\hline
\end{tabular}

$26 \%$ said they liked speaking CE, and 19\% said they were unsure. The main reason respondents liked speaking $\mathrm{CE}$ was that it was intelligible $(47 \%)$, they used it for fun with friends $(27 \%)$, and it represented their Chinese identity (20\%). Those that did not like speaking CE stated that it was not attractive $(23 \%)$, intelligible $(23 \%)$, or standard $(19 \%)$, and that they wanted to speak English like a NS (19\%). Those that were unsure whether they liked speaking CE or not also stated that they wanted to speak like a NS $(27 \%)$, though they used CE for fun with friends (18\%).

Participants were also asked to give their attitudes towards CE based on a set of closed-choice questions, which were also analyzed according to whether the speaker spoke CE or not in order to determine whether speaking $\mathrm{CE}$ affected their opinions of CE. The results are presented in Figure 2. For those that stated they spoke CE, the majority (74\%) felt that it represented the English spoken

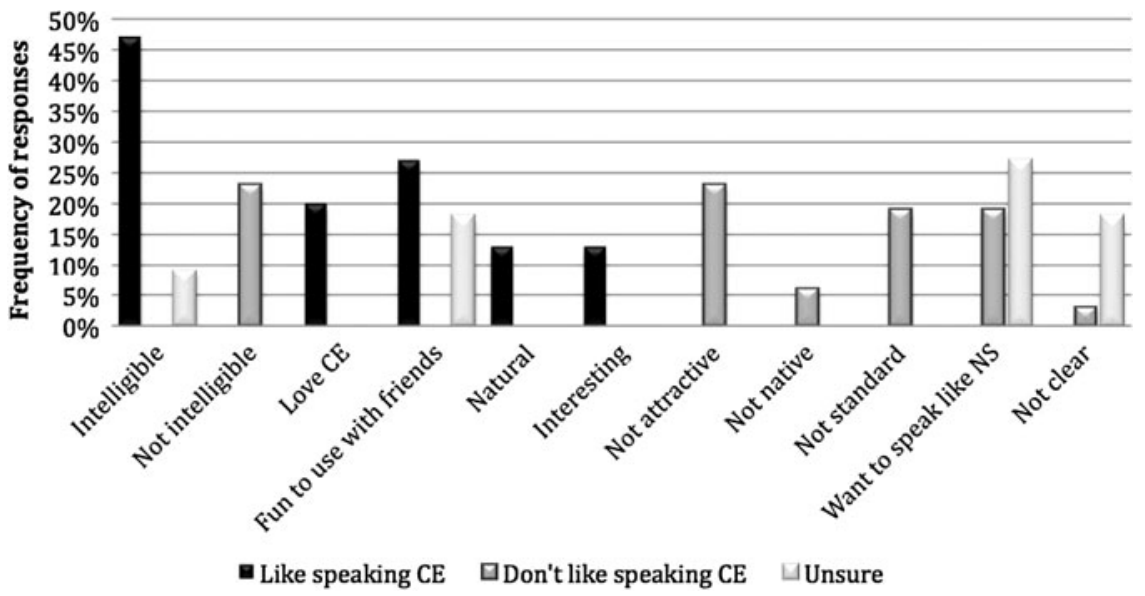

Figure 1: Reasons for liking or not liking speaking CE 


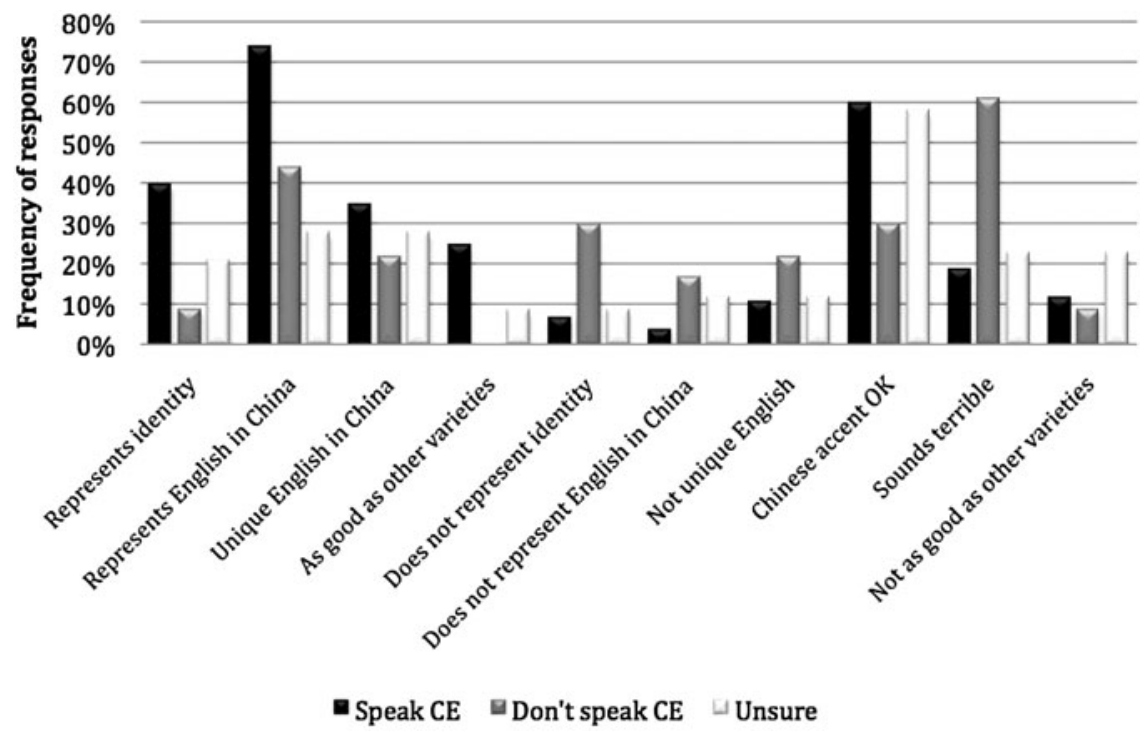

Figure 2: Attitudes towards CE

in China and that it represented their identity $(40 \%)$. These respondents also felt it was a unique variety of English in China (35\%) and that a CE accent was not a big deal, as long as the speaker's English is understandable (60\%) and nearly $25 \%$ felt it was as good as any other variety of English.

Interestingly, nearly half of those that stated they did not speak $\mathrm{CE}$ also felt that $\mathrm{CE}$ represents the English spoken in China and over 30\% felt that a CE accent was not a big deal if the speaker's English was understandable. However, these respondents perceived $\mathrm{CE}$ more negatively than those who stated they spoke CE, as over $60 \%$ of those that did not speak CE thought a CE accent sounded 'terrible', compared to only $20 \%$ of those who said they spoke CE. In addition, over $30 \%$ felt it did not represent their identity and $22 \%$ felt it was not a unique variety of English in China. Those who said they were unsure about speaking CE had positive attitudes towards CE for the most part, with $58 \%$ stating that a $\mathrm{CE}$ accent was not a big deal if the speaker's English was understandable, and 28\% stating that it represents the English spoken in China and is a unique variety of English.

\section{Discussion}

This study confirms the findings from previous research (cf. He \& Li, 2009; He \& Zhang, 2010) that attitudes towards $\mathrm{CE}$ in China have become more positive across time. The majority of the respondents believed that $\mathrm{CE}$ represents the English spoken in China and that a CE accent is not a big deal if the person's speech is intelligible. Over a third believed that it is a unique variety of English in China, and over a quarter believed it represents their identity. Over a half also believed it was normal to speak English with a Chinese accent. More negative attitudes were expressed about the linguistic features of $\mathrm{CE}$, with over a third perceiving it to be ungrammatical and nearly half agreeing that $\mathrm{CE}$ sounds 'like the speaker has not learned "correct" English'. This finding - the division between positive attitudes towards the status of the variety vs. negative attitudes towards the linguistic features of $\mathrm{CE}$ - indicates that some speakers of English in China are experiencing 'linguistic schizophrenia' (Kachru, 1983). On the one hand, they accept CE's existence and believe it represents the English in China, but on the other hand, they view the linguistic features of CE negatively, most likely due to a continued comparison of CE's features to those of 'native' varieties of English. Interestingly, this has also been found for speakers of Hong Kong English (see Groves, 2011; Hansen Edwards, 2015). There is also a divergence in how the respondents view linguistic features of CE. Those that believe $\mathrm{CE}$ is a real variety of English view the features of CE as innovations while those who do not view $\mathrm{CE}$ as real view them as errors, to use Bamgbose's (1998) terms.

Another finding is the schism between accepting $\mathrm{CE}$ and speaking $\mathrm{CE}$. While most of the 
Table 5: Defining a native speaker

\begin{tabular}{|c|c|}
\hline Davies (2008) & This study \\
\hline 1. NS by birth (that is, by early childhood exposure) & $\begin{array}{l}\text { 1. Born and raised in China } \\
\text { (learned English in CE environment) }\end{array}$ \\
\hline 2. NS by virtue of being a native user & 2. Learned English through education \\
\hline $\begin{array}{l}\text { 3. NS (or native speaker-like) by being an exceptional } \\
\text { learner }\end{array}$ & $\begin{array}{l}\text { 3. Speakers of English in China speak China } \\
\text { English (not other varieties of English) }\end{array}$ \\
\hline $\begin{array}{l}\text { 4. NS through education in the target-language } \\
\text { medium }\end{array}$ & 4. Parents speak CE or Chinese \\
\hline \multirow[t]{2}{*}{ 5. NS through long residence in the adopted country } & 5. Speaks English with advanced proficiency \\
\hline & $\begin{array}{l}\text { 6. Frequent use of English/early age of learning/ } \\
\text { unique accent }\end{array}$ \\
\hline
\end{tabular}

respondents were generally accepting of CE, very few actually wanted to speak it. There also appears to be a relationship between speaking $\mathrm{CE}$ and attitudes towards CE. Speakers of CE were much more likely to agree that it represented their identity and that it was as good as another variety of English, and were much less likely to have negative perceptions about the linguistic features of $\mathrm{CE}$, while the reverse was true for non-speakers of CE. As these findings illustrate, perceptions about $\mathrm{CE}$ may depend on whether the respondents speak CE or not.

Surprisingly, the construct of the NS of English was rarely evoked in the discussions of CE. In response to why speakers of CE did not like speaking CE, only a few respondents stated CE was not the 'standard' and said they wanted to speak like NSs and of those who were unsure, only three respondents wanted to speak like a NS. However, while speakers of English in China may not directly refer to inner circle norms in their discussion of $\mathrm{CE}$, it is clear that for many, $\mathrm{CE}$ is a learner variety and that the features of $\mathrm{CE}$ are errors, rather than markers of a Chinese identity, as noted above.

The study also found that whether the respondents spoke CE affected their attitudes towards the legitimacy of CE. Of the respondents who said CE was a real variety of English, nearly half $(49 \%)$ spoke CE. In contrast, of those who said $\mathrm{CE}$ was not a real variety of English, the majority (61\%) did not speak CE. The study also found that speaking $\mathrm{CE}$ had an effect on perceptions of NSs. The majority of those that spoke CE said one could be a NS of $\mathrm{CE}$, while a large percentage (39\%) of those that did not speak CE stated that one could not be a NS of CE.
The answers from those respondents who stated that one could be a NS of CE were analyzed to determine which criteria respondents employed to define a NS of CE. These criteria are compared with the summary of different views of what a NS is by Davis (2008), and presented in Table 5 .

The criteria the respondents use to define NS are similar to those employed in most applied linguistics research: environment, education, proficiency, and age of learning. The criteria themselves, therefore, are not necessarily different. It is how the criteria are defined that differs. The respondents stated that beginning to learn English at an early age was one reason why one could be a NS of English. Traditionally, 'early age' is defined as 'birth' or 'early childhood' but for the respondents, age of English learning is typically related to education as the majority started learning English in primary school. The respondents also stated that English education was a reason why $\mathrm{CE}$ could be a native language. For the majority of the respondents, English would not be a medium of instruction for all courses, but rather a subject taken daily or several times a week. Environment was another criterion; which for the respondents refers to the fact that they are living in an environment of CE. Proficiency is a particularly important definition of a NS, as NS proficiency is often used as a yardstick with which to assess the language of 'learners', typically to determine deficiencies or errors. However, the respondents defined proficiency as 'the ability to use the language well', which is a more appropriate definition of proficiency in a world English context.

While some researchers argue that the NS construct is obsolete (cf. Wang, 2012), I would argue 
that the construct is so ingrained in the psyche of the language learner that it is difficult for users of English to ignore. Instead, the construct has been claimed and redefined in two ways. Firstly, NS of what? Traditionally, the implication of NS is an inner circle English, but now speakers of English in outer and expanded circle countries are claiming the 'NSness' of their own variety of English. According to the respondents, their 'nativeness' is 'nativeness' of CE, which is different from the 'nativeness' of another variety of English.

The second way in which the NS construct has been changed is in terms of what proficiency one has to attain, and most importantly, how (against what norm?) this proficiency is measured. Traditional NS proficiency is measured against an inner circle, typically monolingual, norm whereas for most new Englishes, speakers are typically multilingual, and their competency in English cannot be measured against a norm or model that is not relevant or indigenous to the context in which the language is spoken.

\section{Conclusion}

While this study was small-scale as only 123 speakers of English were surveyed, the level of representation of the speakers in terms of regions of China provides some indication of the attitudes towards $\mathrm{CE}$ across China. The current study provides confirmation of the changing attitudes towards $\mathrm{CE}$ and further explores how speakers of $\mathrm{CE}$ and nonspeakers of CE differ in their views of CE, as well as why respondents hold these opinions. There is no doubt that $\mathrm{CE}$ is gaining recognition and acceptance within $\mathrm{CE}$, particularly by those who state that they speak CE, and that the status of English is changing in China, from an exonormative language, to one of China's own. With the change of the status of English in China comes a change in the status of the NS construct, which this study shows is undergoing redefinition in China. As the findings from the current study illustrate, further research is needed on the NS construct in light of world Englishes, particularly among those who speak a new English such as CE, in order to examine how this construct is being claimed and redefined by speakers of English around the world.

\section{Note}

1 Mainland China consists of 22 provinces, five autonomous regions, and four municipalities.

\section{References}

Bamgbose, A. 1998. 'Torn between the norms: Innovations in world Englishes.' World Englishes, 17(1), 1-14.

Bolton, K. 2008. 'English in Asia, Asian Englishes, and the issue of proficiency.' English Today, 24(2), 3-12.

Bolton, K. \& Graddol, D. 2012. 'English in China Today.' English Today, 28(3), 3-9.

Davies, A. 2008. 'The native speaker in applied linguistics.' In A. Davies \& C. Elder (eds.), The Handbook of Applied Linguistics. Malden, MA: Blackwell, pp. 431-50.

Groves, J. M. 2011. “"Linguistic schizophrenia” in Hong Kong.' English Today, 27(4), 33-42.

Hansen Edwards, J. G. (2015). 'Hong Kong English: Attitudes, identity, and use.' Asian Englishes, 17(3), 184-208.

He, D. \& Li, D. 2009. 'Language attitudes and linguistic features in the "China English" debate.' World Englishes, 28(1), 70-89.

He, D. \& Zhang, Q. 2010. 'Native speaker norms and China English: From the perspective of learners and teachers in China.' TESOL Quarterly, 44(4), 769-89.

$\mathrm{Hu}, \mathrm{X} .2004$. 'Why China English should stand alongside British, American, and the other "world Englishes".' English Today, 20(2), 26-33.

Kachru, B. B. 1983. 'Models for non-native Englishes.' In K. Bolton \& B. B. Kachru (eds.), World Englishes: Critical Concepts in Linguistics: Vol. 4. London: Routledge, pp. 108-130.

Kirkpatrick, A. 2007. World Englishes: Implications for International Communication and English Language Teaching. Cambridge: Cambridge University Press.

Kirkpatrick, A. \& Xu, Z. 2002. 'Chinese pragmatic norms and "China English".' World Englishes, 21(2), 269-79.

Schneider, E. W. 2010. 'Developmental patterns of English: Similar or different?' In A. Kirkpatrick (ed.), The Routledge Handbook of World Englishes. Routledge: London; New York, pp. 372-84.

Singh, R. (1998). Introduction. In R. Singh (Ed.), The Native Speaker: Multilingual Perspectives. Sage Publications: New Delhi, India, pp. 26-44.

United States Census Bureau. 'Population clock.' Online at $<$ http://www.census.gov/popclock/> (Accessed October 8, 2014).

Wang, L.-Y. 2012. 'Moving towards the transition: Non-native EFL teachers' perceptions of native-speaker norms and responses to varieties of English in the era of global spread of English.' Asian EFL Journal, 14(2), $46-78$. 